\title{
The role of the teacher in a blog as a facilitator of students' language development
}

\author{
Suzan Severo de Severo \\ UniRitter \\ Patrícia da Silva Campelo Costa \\ Universidade Federal do Rio Grande do Sul - UFRGS
}

\begin{abstract}
Resumo
Este trabalho apresenta um estudo sobre o uso da comunicação mediada por computador como meio de propiciar a aprendizagem de inglês como língua estrangeira (LE). Além disso, a pesquisa investiga como um blog pode ser utilizado para promover a aprendizagem em LE e examina de que maneira tarefas online podem ser úteis nesse ambiente, de modo a explorar as vantagens pedagógicas do blog. Para essa pesquisa, um blog foi criado, no qual foram postadas atividades semanalmente. As tarefas foram realizadas por um grupo de aprendizes brasileiros de inglês como LE que estavam no nível intermediário. Com base nos dados e opiniões dos alunos, verificou-se que o blog pode ser um recurso eficaz para otimizar o processo de aprendizagem em LE quando as tarefas propostas pelo professor permitem que os aprendizes pratiquem significativamente a língua. Embora as atividades propostas não sejam intrinsecamente colaborativas, os alunos foram capazes de interagir com seus colegas, lendo e comentando suas postagens.
\end{abstract}

Palavras-chave: blog digital, prática de produção textual, professor de LE.

\begin{abstract}
This work presents the findings of a study on the use of computer mediated communication as a means for learning English as a Foreign Language (EFL). More specifically, it aims at investigating how a blog can be used to foster students' learning of this foreign language (FL). It examines how online tasks could be useful in this environment so as to explore the pedagogical advantages of a blog. For this research a blog was created on which assignments were posted weekly. The tasks posted on this blog were carried out by a group of Brazilian EFL learners who had an intermediate level of English. Based on the data and the students' opinions, it was found that the blog can be an effective resource to optimize the learning process of a FL when the tasks proposed by the teacher allow students to practice the language meaningfully. Although the activities proposed were not intrinsically collaborative, students were able to interact with their peers by reading and commenting their posts.
\end{abstract}

Keywords: digital blog, writing practice, FL teacher. 


\section{INTRODUCTION}

The use of computer-mediated communication (CMC) can be a way to foster students' practice of a foreign language (FL), since digital tasks can provide opportunities for language practice as learners interact online. Among several tools which can be used by students to develop communicative skills, blogging is a practice that has been widely used to optimize participation in online communities and practice of reading and writing skills. But what is the role of the teacher when this blogging practice is taken into consideration in the learning process? What types of tasks are more likely to promote the development of reading and writing skills? What is necessary to maintain students engaged in virtual literacy practices? Teachers should reflect about their role as more proficient individuals, who are in charge of designing tasks, promoting collaborative work and interaction as well as guaranteeing equality in participation. According to Vygotsky's sociocultural theory (1986), which underlies this work, the learning process is considered as a social process in which individuals develop knowledge by interacting with others. Learning is not a solitary process in which the learners interact only with the input they are exposed to.

Concerning the CMC learning environment and mindful of the importance of the human factor in the learning of a FL, we assume that teaching in an online space involves not only distributing mechanical exercises (POLONIA, 2003) and providing input (FROMMER, 1998) for students to have contact with or be exposed to the language. It is indeed much more than this, since the teacher has the responsibility of promoting meaningful motivating tasks and is supposed to propose activities which are in consonance with students' interest.

Therefore, this study aims at investigating the teacher's role in a CMC setting, as well as analyzing activities which may encourage students to write meaningful texts. Collaborative work is also examined in terms of how it can be fostered among students through the practice of reading and commenting on their peers' texts. Hence, this research is based on studies about the use of the online environment to teach a foreign language (WARSCHAUER, 1997; HAMPEL, 2006; LEE, 2011; FAGEEH, 2011). Such studies deal with the role of the teacher as a facilitator of the process of learning in a CMC setting. This work can be a means to promote teachers' reflection on pedagogical practices in virtual spaces. It is known that teachers have made use of the Internet as a tool to increase practice in the FL (LEE, 1997; WANG, 2004; GODWIN-JONES, 2005). However, it is necessary to think of a framework to develop activities which can be delivered online and which involve students in meaningful language practice. 


\section{LITERATURE REVIEW}

According to Warschauer (1997), CMC has a great impact on the development of communicative skills in a foreign language since it optimizes students' active participation. This may be accomplished as students interact by participating in communities of practice (LAVE; WENGER, 1991) or affinity groups (GEE, 2004) when they are online. The author states that communication in the context of $\mathrm{CMC}$ can be "more equal in participation than face-to-face discussion, with those who are traditionally shut out of discussions benefiting most from the increased participation" (Warschauer, 1997, p. 473). Certainly, considering an online classroom, these opportunities of participation can be triggered by the teacher who may provide cues for students' participation. This possibility of offering an online environment which is surrounded by diverse interactions among teacher and students may lead to meaningful social practices in the classroom. $\mathrm{CMC}$, as well as face-to-face learning when seen through a sociocultural perspective, assumes that learning happens in social practices.

Therefore, considering that learning happens in social practices, a framework for the development of tasks focused on collaboration and meaningful production in an online environment has to be taken into account. Fageeh (2011, p.33) states that 'blogging as a feature of CMC provides a viable environment for collaboration in which EFL learners can share their emotions and ideas in cyberspace". Promoting the practice of a FL by asking students to write about their feelings is a way of engaging students in meaningful reading and writing practice. Campbell (2003, s.n.) defines a weblog as "an online journal that an individual can continuously update with his or her own words, ideas, and thought". He also mentions the interactive nature of a weblog since this tool allows readers to make comments and hence maintain interaction. The author presents the notion of tutor $\log ^{1}$, which may be used to give daily reading practice to the learners, promote exploration of English websites, encourage online verbal exchange by use of comment buttons and provide class or syllabus information. With respect to reading practice, the author states that the teacher is someone who can perceive students' interests and who is likely to correspond to students' expectations. Campbell (2003) also claims that a weblog can be used as a means of raising students' curiosity about a FL:

Any entry made by the tutor can and ought to encourage further exploration of the Internet in English by linking to related articles, and content based websites. For those learners reluctant to step outside the comfort of exploring the Web in their native language, being led to interesting English language sites will increase their confidence and help to overcome their aversion. (Campbell, 2003, s.n.)

\footnotetext{
${ }^{1}$ In this text, the terms tutor and teacher will be used interchangeably.
} 
According to Vygotsky's (1986) zone of proximal development, learning happens through the interaction of a less proficient individual with a more proficient one. Thus, based on the Vygotskian sociocultural theory of learning, students' interaction promotes learning as a more proficient student may scaffold the learning of a less proficient one. Then the teacher and the student's peers can be seen as more proficient language users who can scaffold the learning process. In turn, the teacher is responsible for designing assignments that may foster collaborative work among students and consequently may trigger the development of communicative skills. Thus, the teacher has the role of a facilitator of the learning process. Then through tasks proposed by the teacher the learners may be able to develop their language by interacting with more proficient peers and by being exposed to language which is beyond their current knowledge.

Besides, the habit of reading and commenting blog postings can be a way to trigger reading and writing practices in a FL. In order to encourage online verbal exchange by the use of the comment button of a blog, which is useful to prompt reflection and participation, the teacher may ask questions and provide hyperlinks access. In relation to hyperlinking, Furstenberg (1997, p. 23) states that a "hypermedia environment, (...) encourages exploratory and research-oriented inquiry." Furthermore, practicing EFL through a digital resource may facilitate students' access to authentic material as well as optimize the time of exposition/input to the FL.

Fageeh (2011) examined the effect of blogging on writing proficiency and students' attitudes towards weblog use. His study has shown that weblogs can build motivation and increase opportunities for authorship and readership. Thus learners who do not have many opportunities of contact with the FL can have the chance to cope with the language in a genuine environment where they can express their thoughts to a real audience.

In an online learning environment, interaction may happen even when the student does not express it clearly by responding to their peers' comments or asking direct questions to them. This is to say that when students interact with the material which was produced by their colleagues (comments, for example), they are in some way having an active role since they are making sense of texts and reflecting upon their peers' ideas. Collins and Berge (1996) discuss the importance of interaction in an online learning environment as well as the changing roles of teachers and students. The authors state that in terms of learning and interaction, there are two types: a student-content interaction and a student-content-student interaction. They state that the tutor has to provide an environment in which both kinds of interaction can occur. According to Collins and Berge (1996), even the type of interaction in which the students interact only with the content is positive since it gives them an opportunity 
to be exposed to authentic versions of the FL. Besides, this content is produced by people in meaningful social practices.

Blogging can be considered a literacy practice since it involves social practices around texts. Barton and Hamilton (1998) explain that:

\begin{abstract}
Literacy does not just reside in people's heads as a set of skills to be learned, and it does not just reside on paper, captured as texts to be analysed. Like all human activity, literacy is essentially social (...). (Barton and Ha milton 1998, p. 3)
\end{abstract}

Therefore when there are student-content interactions (besides interactions between individuals), the process of literacy can take form as materials produced by social demands are read and written. This way, students engage in meaningful practice and are involved in reading and reflecting practices about content. Thus it is important that teachers think of activities which are designed for the practice of meaningful texts, focused on meaning instead of form.

\title{
METHODOLOGY
}

In order to create a setting to raise data on the role of the teacher as a tutor in a virtual space, a blog was designed which was run by a tutor. Through this blog, where assignments on writing and reading were provided, there is an analysis of the types of activities which are more likely to help students practice writing meaningful texts. The blogging tool allowed the teacher to work with hyperlinks and other external resources to support the material published for students. Videos, segments of movies, paintings and other resources were used in order to motivate students to reflect on the topics of each class. Moreover, the tutor tried to establish interaction among students by fostering comments on their peers' answers and comments. The tutor himself made comments and elicited questions to trigger responses.

The participants were six volunteers from a private English course school who agreed to take part in the project as a means of increasing their opportunities for practicing EFL. The participants' English proficiency level was intermediate. It is important to mention that all the volunteers were in their late 20 's, and although they had some familiarity with computers and internet, they could not be considered digital natives ${ }^{2}$ and were not used to reading and posting comments in blogs.

During the first two weeks, students were supposed to complete their profiles and write a text introducing themselves so that they had the opportunity to get to know their peers.

\footnotetext{
${ }^{2}$ By digital natives we mean those people who have grown up immersed in dig ital technology.
} 
The students were also asked to upload a photo to their profiles and make a comment on their peers' profiles. After that, the tutor proposed activities aimed at encouraging students to use language to share personal experiences - a decision based on Willis' (1996) proposal of a methodological framework for the designing of tasks. ${ }^{3}$ According to the author, "sharing personal experience" is an open task ${ }^{4}$ which encourages students of a FL "to talk more freely about themselves and share their experiences with others" (Willis, 1996, p. 27). Throughout the following weeks, students were supposed to talk/write about childhood memories, to share their ideas of a perfect day, to offer their opinions about a piece of art or to report a situation in which things could have been different. In order to motivate students, a pre-task moment was provided, which was composed of an introduction to the topic through music, poems or videos.

Individual feedback on the written texts composed by the students was sent by email by the teacher. However, the students were able to post their comments freely, before the feedback moments, so as to maintain the genuine feature of the blog as an interactive tool. Even though the main purpose of the activities was not to focus on form, whenever the tutor saw that the students needed to review a specific linguistic structure, he provided a link to a website where students could read more information on this specific language topic. The website was a suggestion, and the learners were not required to perform any extra work, since they had only an extra source of research. The purpose of providing these links, more than working on structural aspects of language, was to encourage students to work autonomously and to develop a sense of accountability for their learning process. In other words, students have to acknowledge that they are responsible for their process of learning and that being successful in this process will depend greatly on their engagement and their attitudes towards the language.

After completing all the tasks, the participants were requested to answer an open questionnaire reporting their experience in the project and their perceptions of it. The objective was to analyze their perceptions of the advantages of using a blog as a tool to improve their English as well as to analyze the types of difficulties they may have faced when using the tool. The questionnaire was composed of eleven questions and was written in the students' native language, in order to make them more comfortable when answering the questions. Nevertheless, a translation is provided below in Table 1.

\footnotetext{
${ }^{3}$ According to Willis (1996, p. 23), "tasks are always activities where the target language is used by the learner for a commun icative purpose (goal) in order to achieve an outcome."

${ }^{4}$ In her study, Willis distinguished closed tasks and open tasks. According to the author "closed tasks are ones that are highly structured and have very specific goals" while "open tasks are ones that are more loosely structured, with less specific goal". (W illis, 1996,p.28)
} 
Table 1 Questionnaire

1. What is your opinion about the experience of reading and commenting on the texts in the blog? 2 . Did you have any difficulty w ith the tool we have used (blog)?

3. Has this experience affected the way you learn English (or not)?

4. Did you read and comment on your peers' posts when using the blog? Why (why not)?

5. Do you think that you interacted with your peers during the experience? Why (why not)?

6. Do you think that you worked collaboratively with your peers? Why (why not)?

7. Do you think you were able to express your ideas and write texts which were meaningful for you? Why (why not)?

8. Would you like to have participated more? If yes, to what do you attribute your absence in certain moments?

9. What is your opinion about the activities proposed?

10. Would you have any suggestion about exercises?

11. Would you partic ipate in a Project like this again? Why (why not)?

The objective of this questionnaire was to analyze students' perceptions of using a blog for educational purposes as well as to examine the difficulties they may face when using the tool. Therefore, this research is qualitative and follows an interpretative pattern since it examines perceptions about the process, according to the researcher's point of view and taking into consideration the participants' observations. This way, as seen by Moita Lopes (1994), the interpretative research is a social construction as it is not only focused on objectivity provided by the researcher - it also based on participants' subjectivity.

\section{ANALYSIS}

During the first two weeks, students completed their profiles and posted a text introducing themselves to each other. They were asked to read each other's text, post comments and ask personal questions to their peers. The objective of this activity was to promote social interaction among students in order to create a welcoming atmosphere. Collins and Berge (1996) acknowledge the importance of social interaction in distance teaching. According to them, whenever teaching through a virtual environment, the tutor has to promo te the creation of a setting in which students can start working collaboratively. According to Fageeh (2011), the use of blogs as a tool for developing writing skills can be influenced by affective factors such as motivation and attitudes. In this study, students posted twenty-eight 
comments in response to this first activity. It was clear that they had read their peers' posts because they made comments and asked questions about their classmates' profiles.

Hello Antonio, how are you? You like to travel like me. Do you know any place outside of Brazil? $(\text { Amanda })^{5}$
\[ * * * * * * * * * * * * * * * * * * * * * * * * * * * * * * * * * * * * * * * * * * * * * * * * * * \]

Hi Amanda! Traveling is very nice, isn 't it?

In 2008 I went to Buenos Aires, it is very nice there, I hope I can back there next year. (Antonio)

$* * * * * * * * * * * * * * * * * * * * * * * * * * * * * * * * * * * * * * * * * * * * * * * * * * * * * *$

Hi Antonio, what do you do at Infraero? Where do you intended to do a post-graduation? Hugs, (Laura)

$* * * * * * * * * * * * * * * * * * * * * * * * * * * * * * * * * * * * * * * * * * * * * * * * * * * * * *$

Hi Laura, nice to meet you!

I work as an administrator in the financial department there.

I had already registered at UFRGS to do my post-graduation next year, but I'm still waiting the answer because they need to do an interview with each registered. Hugs... (Antonio)

Some students, however, had difficulty in understanding how to upload their pictures and fill in their profiles. The tutor, then, helped them by providing technical support. According to Berge (1995), for an online study to be effective the technical conditions must be considered. The teacher's role in an online environment goes beyond designing tasks, giving feedback, motivating students and keeping discussions on track. The online teacher has to give some technical support and guarantee that participants are at ease with the tool which is being used. For this reason, the students had two weeks to get used to the blog structure and were oriented to ask for help whenever they had any technical problems.

At this point, some students expressed their concern about making mistakes. Since the objective of the course was to write meaningful texts in the FL, the tutor clarified that the focus of the activities was on fluency rather than on accuracy and that students should not worry about making mistakes, which are part and parcel of the learning process. Similarly, Willis (1996, p. 24) states that "learners need to regard their errors in a positive way, to treat them as a normal part of learning". The tutor also explained that they would receive feedback on meaning and form about their posts by email and that they would be able to edit their posts, correcting possible mistakes.

Although making mistakes is seen as part of the learning process, it may be positive that students feel the necessity of expressing themselves as accurately as possible in order to be understood by their readers. According to Fageeh (2011, p.42), one of the benefits of using a blog to practice language skills is that students "are more concerned on correctness which leads us to consider blogs a potential tool for the development of foreign language linguistic

\footnotetext{
${ }^{5}$ In order to protect participants' identities, all the names have been changed and pseudonyms have been used in each reference.
} 
skills". This kind of concern may be helpful since it pushes students to reflect about language structure.

After the first two weeks, the second assignment was posted by the tutor. As mentioned by Collins and Berge (1996, s.p.), when teachers post activities in an online environment, they "become expert questioners rather than providers of answers". The activity got students to express themselves in answer to a question from the tutor. He asked them what their perfect day would be like, to engage them in writing practice. In order to contextualize the topic and motivate them to express themselves in a freer way, the tutor provided a link to a song $^{6}$ (which is about a perfect day) and offered an example of a person's opinion on what a perfect day should be like.

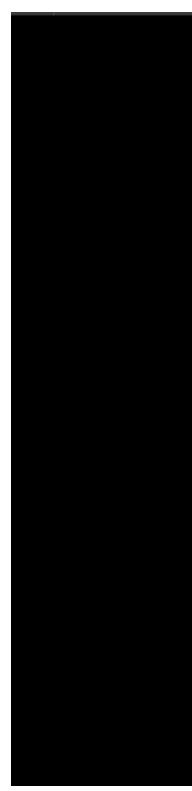

2. Now that you have already listened to the song and read the lyric, read what a person from Noblesville, a city in the USA, said about his/her perfect day:

"Myy perfect day would be spending a whole day with my dead grandmother. Like, she would come back to life for one day...or one week.... as beautiful as she was bo to steak in shake for lunch, go on walks, go to the pool if it was summer, etc. Also, maybe she could take me to kings island. That'd definitely be a perfect day".

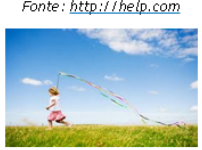

3. What about your perfect day? How would it be for you if money or time were not a problem? What would you do on such a "perfect day?"

Share your idea of a perfect day with your classmates by posting it in the comments here:

Publicado em Uncategorized | Edita

Getting to know each other!!! From Dec, 1st to Dec, 8th.

DEZ1 Pubicado por sueurres

Figure 1. Blog page printscreen

There were six comments to this $\operatorname{post}^{7}$, a fact that may indicate students showed interest in sharing their ideas of a perfect day.

"My perfect day would be doing simples things. First, I would like to wake up without an alarm clock and to have the breakfast in the bed. I would like to spend more time with my mom, my dad and my brother, in some beautiful beach. We would relax and have good meals. I would like to swim and walk on the beach with them".

*************************************************************

"Hi all,

Hope you had a perfect day last Xmas!!! xD My perfect day was like last weekend when I was with my

\footnotetext{
6 "Perfect Day" is a song written by Lou Reed in 1972.

${ }^{7}$ Three examples are included in this article due to limitation of space.
} 
friends having a real good time, sharing good news and plans for the future. Also, it would be a day at the beach, a sunny and beautiful day.

Best,"

“In a perfect day I wouldn't worry about time. I would wake up, take a good breakfast and would go to the beach in a such sunny day. During the night I would have a magnificent dinner with my bride and we would watch a good movie embraced, without problems and without worries about time..."

Students expressed themselves in varied forms, they used the second conditional and the past to express their ideas of what a perfect day would be like. Therefore, after being motivated by a song and being exposed to language in use, students had the opportunity to use the language they had learned in order to express themselves freely, so they were not asked to use any specific form. According to Willis (1996, p. 18) "learners need more chances to use the target language with each other, not just to practice forms, but also to achieve results".

According to Willis' (1996) framework, there are three distinct phases in task-based learning. The first phase is the pre-task when students are introduced to the topic, the second one is the task cycle when students are able to use the language more freely, and the third phase is the language focus when students have contact with specific language forms that can be used to convey a specific meaning, as expressing a hypothesis, for example. Hence, after performing an activity which was based on a free conversation, the next activity (in Figure 2) emphasized the third phase indicated by Willis (1996).

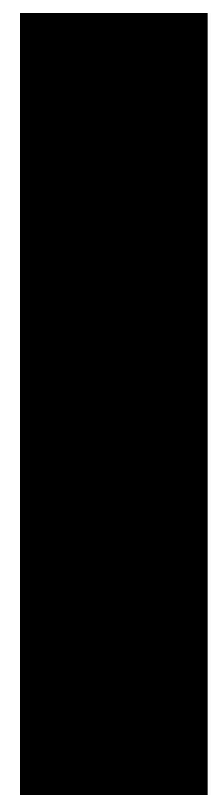

Exercises

1. Choose one or two of

What would you do if...?
Objective: Work with se

second conditionals (if + past simple, would + base form of the verb )

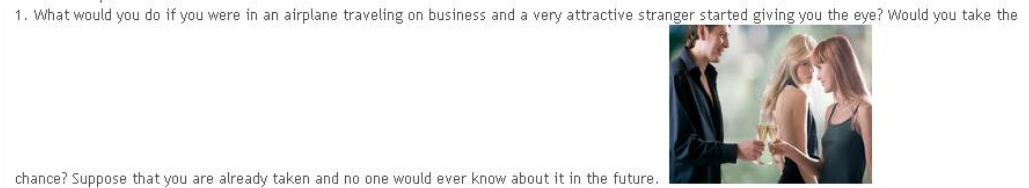

2. Would you agree to wash toilets for five years if that meant to wash hunger away from the plane t?

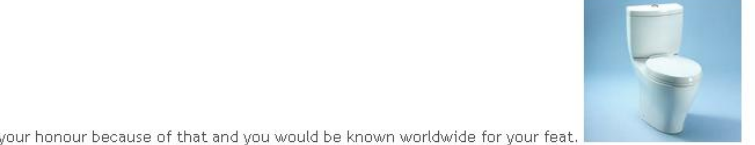

your honour because of that and you would be known worldwide for your feat.
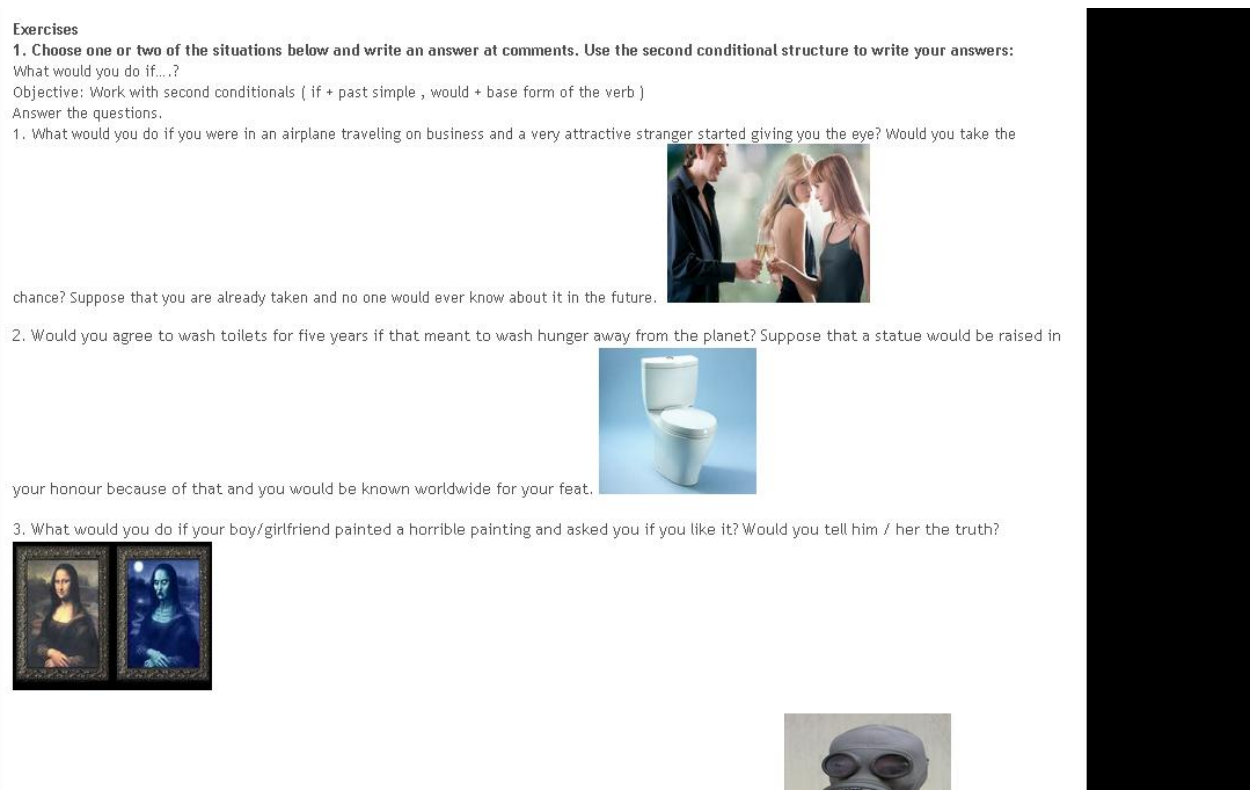

Figure 2. Blog page printscreen

The instructions of the exercise made it explicit that students should use the second conditional form to write their answers. Before starting the activity, the tutor provided an 
explanation of the second conditional use and structure. As can be seen in the following extracts, all the participants used the requested form:

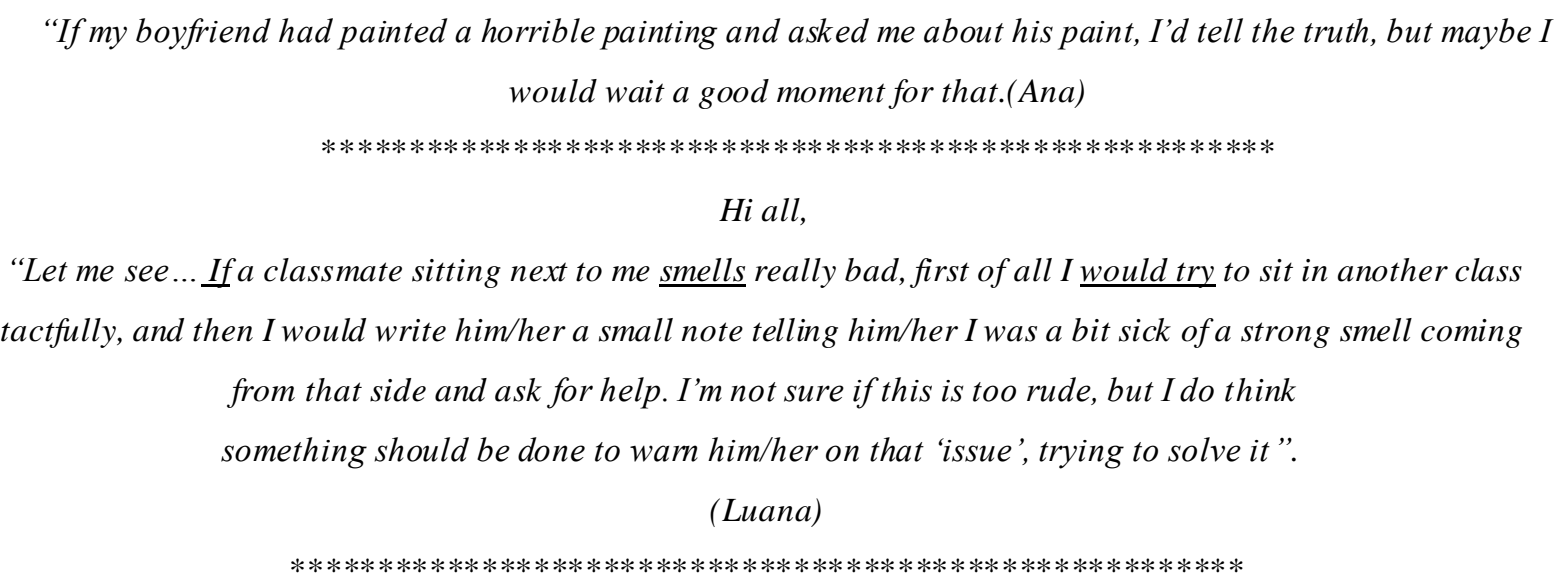

"Hi, Luana very good your solution for the situation...

Other answer:

If I had seen a coworker doing something wrong, like to take away from office some materials to home. I'd talk with him/her about the situation, if he/she was really my friend. But if I hadn't enough nearness I'd say to my boss take more attencion but without to tell exactly what I had seen".(Ana)

$* * * * * * * * * * * * * * * * * * * * * * * * * * * * * * * * * * * * * * * * * * * * * * * * * * * * * * *$

Hi Ana, Thanks for your comment!!! (-)

You also gave a good solution to that situation. If the referred coworker is your friend, you have to wam him/her. I think it is the most fair and honest action to take in such a case.

Best,Luana

Willis (1996, p. 102) states that "language analysis activities should not consist of decontextualized presentation and practice of language item in isolation". It is important to mention that although this type of exercise was more guided, it was in line with the perspective adopted in this work since students were still talking about things which they really meant and they were not only completing gaps with the target form out of context. Besides, students were able to read each others' posts and comment on their peers' hypotheses. In the previous extracts, it can be seen that Ana and Luana make comments on each others' alternatives for each situation.

The fourth activity proposed was about childhood memories. Before asking students to share their childhood memories, the tutor provided a link to a song by Madonna ${ }^{8}$ (which is about childhood memories) and asked them to complete the lyrics.

\footnotetext{
8 “This Used to Be My Playground” is a song performed by Madonna.
} 
Willis (1996) presents a framework for teaching/learning a FL based on former studies about how languages are learnt. The author suggests several task-based activities which encourage real communication in the FL, such as listing, ordering and sorting, comparing, problem solving, sharing personal experience and working with creative tasks. From the different types of tasks exemplified by the researcher, "sharing personal experience" seems to be in consonance with what is proposed in this study since the tasks in the blog discussed here helped students to talk about themselves and share their feelings, past experiences and thoughts. As reported by Willis (1996, p.27), "the resulting interaction (in this type of sharing personal experience activity) is closer to casual social conversation in that it is not so directly goal-oriented as in other tasks". In the task proposed in the current study, students were invited to write about their own childhood memories, after listening to the song and completing the lyrics.

On Sundays my family used to go to my grandmother's houses. I liked to climb trees, to play with my brother and with my cousins, to study. I used to help my parents with their little store since I had five years old. On vacations we used to go to Cidreira beach.(Ana)

$* * * * * * * * * * * * * * * * * * * * * * * * * * * * * * * * * * * * * * * * * * * * * * * * * * * * * * *$

When I was child, I was a very quiet girl. I have a sister and we played together all the time. My sister is older than me, but I'm bigger than her. We jumped rope, played ball, played with dolls, and others plays. I missing that time. (Laura)

$* * * * * * * * * * * * * * * * * * * * * * * * * * * * * * * * * * * * * * * * * * * * * * * * * * * * * * *$

When I was a child I stayed a long time in the street, I used to play football, hide-and-seek... There were a old house in my street, and my neighbors and I thought it was haunted... Good times... (Antonio)

Although the use of the "used to" form to talk about habits in the past is presented in the lyrics and is included by the teacher in the question, students were not asked to adopt any specific language form at this time. Students were left free to express themselves more naturally using whatever language forms they wanted. Some of them applied the "used to" form while others expressed their ideas writing the simple past. Nevertheless, as it can be seen, both were successful in conveying meaning. In relation to students who are able to convey meaning but not necessarily use the target form, Willis (1996, p. 134) states that "this may be because their own developing language systems are not yet ready to cope with its use or because they do not need the new pattern to express the meaning they want". In this case, students do not necessarily need to employ the target form to express their childhood memories. Instead, they could utilize the simple past to report their past memories. The online tutor does not need to correct students just because they did not use the target form. Otherwise, these learners can feel frustrated. 
The fifth activity posted provided a link to a video in which children talk about their impressions of Edvard Munch's painting “The Scream”. Then after watching the video, the students were required to write about their impression of the same piece of art.

'The first impression that I had of the picture is fear, the man seems scared, alone, helpless. He is looking at something appalling and near from him there isn't any safe place ”. (Laura)

$* * * * * * * * * * * * * * * * * * * * * * * * * * * * * * * * * * * * * * * * * * * * * * * * * * * * * * *$

The picture doesn't bring good feelings for me. I imagine that the man is scared about the people, the bad things that the people are able of doing. I suppose he is screaming for a world of peace". (Antonio)

By providing a link to a video in which people perform a similar task, the tutor is guaranteeing that students are exposed to language examples which can help their own production. According to Furstenberg (1997, p. 2) multimedia materials "provide the user with a rich context for learning, a high degree of immersion, and the potential for varied interactions". When students watch the video, they are being exposed to more input in the FL. Moreover, their comments showed that they interacted with the material since they made meaning out of it. As was mentioned above, for Collins and Berge (1996), it is important that the online tutor considers two types of interaction: the student-content interaction and a student-content-student interaction. In this activity, we can observe that both kinds of interaction occurred, since students were exposed to an authentic version of the FL, made meaning out of it, and also could read and comment on their peers' opinions (even though they were not asked to make those comments).

One of the roles of the online tutor is to motivate students by asking questions, calling them to participate, complimenting them for their comments, and so on. The online tutor has to avoid using ready-made automatic phrases like "Well done!" "Nice"! More than designing tasks to be done online, the tutor has to show interest in the students' practice. That is to say that the online tutor has to demonstrate that he really reads and reflects about students' answers so that they feel that what they wrote was relevant and so that they will feel motivated to write more. Moreover the online tutor also has to act as a motivator, calling students to participate, as can be observed in the following posts.

\section{Hi everyone,}

Luiza, Bella and Sophia have already told us about their impressions on Edvard Munch's painting, And how about you? ... What are your impressions? ...I'm so curious to hear from you. Please, leave a comment here and tell us about your impression on the painting! 
Hi, Antonio

That's nice to see you around here! I totally agree with you, Sophia and Bella are SO cute. You know...?, there is an expression that is "scared to death", it means "extremely scared". So, we could say that the man seems to be scared to death.

Hugs, (teacher)

At the end of the project, the participants answered an open questionnaire in order to reflect on the experience of practicing the FL by reading and writing texts published in a blogging platform. The students reported that they felt motivated to write because they knew their texts would be read by their peers. One student also reported that she could improve her vocabulary knowledge as well as the language structure:

"I think that it is important to write in English, because it intensifies not only the vocabulary, but also grammar aspects. When we study by ourselves we do not have a feedback, nobody reads what we are writing, but with the blog we know that other people will read, and maybe, giving opinions, this way the study is more stimulating."

(Ana)

When asked if they had read and commented on their peers' texts, one student said that although he had not commented on his colleagues' texts, he had read all of them. Likewise, another student said that, although she had responded to only some of the classmates' posts, she had read her peers' comments:

I've read all the posts and in some situations... I made a comment on my colleagues' posts . (Laura)

$* * * * * * * * * * * * * * * * * * * * * * * * * * * * * * * * * * * * * * * * * * * * * * * * * * * * * * * *$

I've read all the posts, always. However, I've just posted one comment for the first activity that was about introductions. (Antonio).

Students were also asked if they had interacted and worked collaboratively with their peers. They mentioned that although they had not helped each other directly, they believed that the fact of posting comments was useful to promote practice of the FL:

I believe that, in general, there was collaboration among students.. (Ana)

*** $* * * * * * * * * * * * * * * * * * * * * * * * * * * * * * * * * * * * * * * * * * * * * * * * * * * *$

I am afraid my English is not so good, but I think I have colaborated because I posted comments and my coleagues had to read them (Laura)

The students were also asked if they had found any difficulty in using the tool. One student reported that at the beginning it was a bit difficult but that after being used to the tool 
it became easier. Another student reported that she had had some trouble finding the edit button and so she could not edit her texts after the teacher's feedback:

In the beginning I could not find the blog, but after I had gotten used to it, it became easier. (Laura)

\section{$* * * * * * * * * * * * * * * * * * * * * * * * * * * * * * * * * * * * * * * * * * * * * * * * * * * * * * *$ \\ I could not find out how to delete the activities I had already sent in order to make edition. (Ana)}

The findings from the study conducted by Fageeh (2011, p. 41) showed that weblogs may encourage "students' self-expression in English, ind ucing a revolutionary engagement in writing." The findings of this study corroborate this idea, since students were engaged in reading and writing meaningful texts and sharing their ideas and personal experiences in a social context, guided by tasks proposed by the teacher and mediated by technology. Students also had the opportunity of being exposed to different input in the FL, available in the digital environment. Besides, according to the feedback when answering the questionnaire, the learners recognized the tool as a form of increasing contact with the FL and they felt they were learning from each other. Fageeh (2011, p. 41) claims that "blogging further tends real communication chances in which writing and reading take place in an authentic environment where there is a real, active, interactive audience". Aware of this real audience, students showed their concerns about language structure and appropriateness in order to be understood by their interlocutors.

\section{FINAL REMARKS}

It was found that the use of the blog during the project provided students with more opportunities for reading and writing meaningful texts in the FL. Participants reported that the experience helped them to practice the FL meaningfully, increasing their vocabulary, and that it pushed them to write more accurately since they knew people would actually read their texts. Some students also reported that they felt motivated to write, as they would have some feedback from the teacher and maybe from their peers about their texts. One of the students, Lia, reported that she used to read her peers' comments even though she hardly ever commented back on their posts. The same student described the experience within the blog as a chance of being in contact with the foreign language.

In order to accomplish the activities, the students had to use their previous knowledge, activating the language they had already learned. In addition, they were encouraged to think critically on the issues which were being discussed by presenting their opinions through 
written language. More than reviewing already known vocabulary, the written practice has encouraged them to look for new vocabulary and new ways of expressing their ideas in the FL. According to Mynard (2007, p. 3), “foreign language students need to draw on previously learned language in order to write a blog entry, which means that they are very likely to be reflecting on their understanding of the language as they compose their blog entries". Although in this study, students were not supposed to write any blog entry, just comment on the tutor's entries in the blog, and eventually make comments on each other's comments, they still had to reflect on the language they were learning as well as to search for new vocabulary and new ways to express their thoughts.

Although the activities did not require students to engage in solving collaborative tasks, Lia reported that reading her peers' comments helped her to build her own texts. This practice is in line with the sociocultural perspective since students could learn from each other. In other words, reading their peers' text and commenting on their posts were ways of learning collaboratively without being directly engaged in a collaborative task.

When students read a text posted by the teacher and/or their peers' texts, they are making meaning out of these texts. Thus, the practice of sharing personal experiences by reading and writing meaningful texts may help students to improve their language knowledge and competence. In this process, the tutor acts as a resource provider who uses his knowledge in order to guide the students to construct their own knowledge of the FL. The tutor designs tasks and guides students who engage in challenging activities in order to activate their previous knowledge and construct new knowledge about the FL by doing the activities. Moreover, the tutor acts as a motivator who calls students to participate and promote interaction.

\section{REFERENCES}

Barton D.; Hamilton, M. (1998). Local Literacies: Reading and Writing in one community, London: Routledge.

Berge, Z.L. (1995). Facilitating Computer Conferencing: Recommendations From the Field. Educational Technology. 15(1) pp: 22-30. Available at http://emoderators.com/wpcontent/uploads/teach_online.html

Campbell, P.A. (2003). Weblogs for Use with ESL Classe. The Internet TESL Journal, Vol. IX, No. 2. Available at http://iteslj.org/Techniques/Campbell-Weblogs.html

Collins, M., \& Berge, Z. (1996). Facilitating interaction in computer mediated online courses. Berge Collins Associates. Available at:http://www.emoderators.com/moderators/flcc.html 
Fageeh, A. I. (2011). EFL learners' use of blogging for developing writing skills and enhancing attitudes towards English Learning: An exploratory study. Journal of Language and Literature, 2 (1), 2011.

Frommer, J. (1998). Cognition, context, and computers: factors in effective language learning. In: Muyskens, J. (Ed.). New ways of learning and teaching: focus on technology and foreign language education. Boston: Heinle \& Heinle. pp. 199-223.

Furstenberg, G. (1997). Teaching with Technology: What is it at Stake? ADFL Bulletin, 28 (3) pp.21-25.

Gee, J. (2004). Situated Language and Learning: A Critique of Traditional Schooling. London: Routledge.

Godwin-Jones, R (2005). Emerging technologies messaging, gaming, peer-to-peer sharing: language learning strategies and tools for the millennial generation. Language learning \& technology, 9 (1), pp.17-22.

Hampel, R. (2006). Rethinking task desing for the digital age: A framework for language teaching and learning in a synchronous online environment. ReCALL, 18 (1), pp. 105-121.

Lave, J.; Wenger, E. (1991). Situated Learning: Legitimate Peripheral Participation. New York: Cambrid ge University Press.

Lee, U. (1997), Using Internet Tools as an Enhancement of C2 Teaching and Learning. Foreign Language Annals, 30, pp. 410-427.

Lee, L. (2011) Blogging: promoting learner autonomy and intercultural competence through study abroad. Language Learning \& Technology. 15 (3), pp. 87-109. Available at http://llt.msu.edu/issues/october2011/lee.pdf.

Moita Lopes, L. (1994) P. Pesquisa interpretativa em linguística aplicada: a linguagem como cond ição e solução. D.E.L.T.A. 10 (2), pp. 329-338.

Mynard, J. (2007). A blog as a Tool for reflection for English Language Learners. Asian EFL Journal Professional Teaching Articles, 24. Available at http://www.asian-efljournal.com/pta_Nov 07 jim.php.

Polonia, E. (2003). Parâmetros para procedimentos pedagógicos na aprendizagem de inglês como língua estrangeira em uma rede telemática. Porto Alegre: UFRGS. Tese (Doutorado em Informática na Educação). Programa de Pós-Graduação em Informática na Educação, Universidade Federal do Rio Grande do Sul.

Vygotsky, L. (1986). Thought and language. Cambridge: MIT Press, 1986.

Warschauer, M. (1997). Computer-Mediated Collaborative Learning: Theory and Practice. The Modern Language Journal, 81 (4), pp. 470-481.

Wang, Y. Distance language learning: interactivity and fourth-generation internet-based videoconferecing. CALICO Journal, 21 (2), pp. 373-395.

Willis, J. (1996). A framework for task-based learning. Harlow: Longman. 


\section{AS AUTORAS}

Suzan Severo de Severo é especialista em Processos de Ensino-Aprendizagem de Língua Inglesa pela Uniritter e Docência para o Ensino Profissional pelo SENAC EAD. Possui graduação em Letras pela Universidade Federal do Rio Grande do Sul (2010). Tem experiência na área de Letras, com ênfase em Línguas Estrangeiras Modernas. Atualmente é Orientadora Educacional III - Serviço Nacional de Aprendizagem Comercial (SENAC)- RS.

E-mail: sueufrgs@gmail.com

Patrícia da Silva Campelo Costa é doutoranda em Informática na Educação pela UFRGS e em Linguística Aplicada pela UNISINOS. Possui Mestrado em Linguística Aplicada e Graduação em Letras-Licenciatura Português/Inglês pela UFRGS. Atua também como professora de inglês na Faculdade Dom Bosco de Porto Alegre.

E-mail: patricia.campelo@yahoo.com 